\title{
Kelayakan Finansial Usaha Budidaya Lebah Madu di KPHL Rinjani Barat, Nusa Tenggara Barat
}

\section{Financial Feasibility of Honey Bees Business at KPHL West Rinjani, West Nusa Tenggara}

\author{
Ni Made Wirastika Sari ${ }^{1 *}$, Ngakan Agus Trisantika ${ }^{2}$, Andi Iva Mundiyah ${ }^{1}$, dan Dudi Septiadi ${ }^{1}$ \\ ${ }^{1}$ Dosen Fakultas Pertanian, Universitas Mataram, Mataram, Indonesia \\ ${ }^{2}$ Alumni Fakultas Kehutanan, Universitas Gadjah Mada, Mataram, Indonesia \\ "email: wirastikasari@unram.ac.id
}

\begin{tabular}{|c|c|}
\hline I N F O A RT I K E L & A B S T R A K \\
\hline $\begin{array}{l}\text { Sejarah artikel: } \\
\text { Dikirim } 5 \text { Agustus } 2020 \\
\text { Direvisi } 18 \text { Agustus } 2020 \\
\text { Diterima } 18 \text { Oktober } 2020 \\
\text { Terbit } 31 \text { Oktober } 2020\end{array}$ & $\begin{array}{l}\text { Hasil hutan bukan kayu merupakan sumber daya hutan yang memiliki peran } \\
\text { penting untuk kesejahteraan masyarakat di sekitar hutan, terutama pada kawasan } \\
\text { hutan lindung. Madu merupakan salah satu hasil hutan bukan kayu yang sudah } \\
\text { lama dimanfaatkan di Provinsi Nusa Tenggara Barat. Peningkatan produksi madu } \\
\text { nasional perlu dilakukan untuk dapat memenuhi permintaan madu yang tinggi di }\end{array}$ \\
\hline $\begin{array}{l}\text { Kata kunci: } \\
\text { Kelayakan finansial } \\
\text { Budidaya lebah madu } \\
\text { Hasil hutan bukan kayu } \\
\text { Trigona sp }\end{array}$ & $\begin{array}{l}\text { Indonesia. Salah satu cara peningkatan produksi madu yaitu dengan melakukan } \\
\text { budidaya lebah madu. Tujuan dari penelitian ini adalah untuk mendapatkan } \\
\text { informasi tentang kelayakan finansial di Kesatuan Pengelolaan Hutan Lindung } \\
\text { (KPHL) Rinjani Barat. Pengambilan sampel dilakukan secara purposive sampling } \\
\text { dengan pertimbangan jumlah kepemilikan stup/koloni lebah terbanyak. Metode } \\
\text { penetilian menggunakan metode kombinasi kuantitatif-kualitatif. Analisis }\end{array}$ \\
\hline $\begin{array}{l}\text { Keywords: } \\
\text { Financial feasibility } \\
\text { Honey bees farming } \\
\text { NTFPs } \\
\text { Trigona sp }\end{array}$ & $\begin{array}{l}\text { finansial dilakukan untuk mengetahui kelayakan usaha budidaya lebah madu } \\
\text { dengan menggunakan kriteria investasi NPV, BCR dan IRR di KPHL Rinjani } \\
\text { Barat. Usaha budidaya lebah madu jenis Apis cerana di Resort Malimbu layak } \\
\text { untuk dilakukan dengan nilai NPV }=\text { Rp. } 104.229 .381-\text { Rp. } 1.036 .687 .824 / 10 \\
\text { tahun; BCR }=2,85-5,79 \text {; IRR }=40,92 \%-42,34 \% \text {. Usaha budidaya lebah madu } \\
\text { jenis Trigona sp di Resort Malimbu juga layak untuk dilakukan dengan nilai NPV } \\
=\text { Rp. } 45.491 .153-\text { Rp. } 92.973 .767 / 10 \text { tahun; BCR }=1,21-1,34 \text {; IRR }=23,52 \% \\
-27,91 \% \text {. }\end{array}$ \\
\hline
\end{tabular}

A B S T R A C T

Non-timber forest products (NTFPs) is a forest resource that has an important role for the welfare of the communities around the forests, particularly in protected forest areas. Honey is one of NTFPs that have long been used in West Nusa Tenggara province. Increased national honey production is needed to be able to meet the high demand of honey in Indonesia. One of the way to increase production of honey is by doing beekeeping. This study aims to obtain information about the financial feasibility in Protected Forest Management Unit (KPHL) West Rinjani. Sample collection has been done by using purposive sampling method with consideration of the number of holdings stup/the most bee colonies. Research analysis has been done by using a combination of quantitative-qualitative method. Financial analysis conducted to determine the feasibility of beekeeping using investment criteria NPV, BCR and IRR in KPHL Rinjani Barat. The result show that the cultivation of honey bee Apis cerana types in Resort Malimbu feasible with NPV = Rp. $104229381-$ Rp.1.036.687.824 / 10 years; $B C R=2.85$ to $5.79 ;$ IRR $=40.92 \%-42.34 \%$. Enterprises beekeeping types of Trigona sp in Resort Malimbu also feasible with NPV $=$ Rp. 45,491,153 Rp. $92,973,767 / 10$ years; $B C R=1.21$ to 1.34 ; $I R R=23.52 \%-27.91 \%$.

\section{PENDAHULUAN}

Sumber daya hutan sudah sejak lama dimanfaatkan oleh masyarakat di sekitar kawasan hutan maupun masyarakat secara global. Secara umum nilai manfaat sumber daya hutan dikategorikan menjadi tiga, yaitu manfaat langsung atau direct use value (kayu, hasil hutan bukan kayu/HHBK, 
sarana pendidikan, rekreasi dan tempat tinggal manusia), manfaat tidak langsung atau indirect use value (perlindungan daerah aliran sungai, pembentuk iklim mikro dan penyerapan karbon) dan nilai yang tidak dapat dimanfaatkan atau non-use value (keberadaan hutan sebagai pengawetan keanekaragaman hayati dan warisan budaya) (Bishop 1999; Chen et al., 2015). Tidak dapat dipungkiri bahwa pemanenan hasil hutan kayu (timber extraction) yang dilakukan hingga saat ini baik legal maupun illegal mengakibatkan terus berkurangnya luas tutupan hutan (Damette dan Delacote 2011; Sumargo et al., 2011). Oleh karena itu, paradigma pemanfaatan hasil hutan yang hanya berfokus pada kayu secara perlahan berubah kearah pemanfaatan hasil hutan lainnya, yaitu HHBK dan jasa ekosistem hutan (Sisak et al., 2016).

Terdapat dua cara untuk memperoleh madu yaitu dengan cara perburuan madu (honey hunter) dan dengan cara melakukan budidaya lebah madu (apiculture/beekeeping) (Hilmi et al. 2011). Menurut data Badan Pusat Statistik, jumlah produksi madu di Indonesia yaitu berkisar antara $52-540$ ton/tahun dalam dalam rentang waktu dari tahun 2011-2015 (Badan Pusat Statistik 2012-2016). Produksi madu yang ada di Indonesia umumnya diperoleh dari empat jenis lebah madu yaitu Apis dorsata (lebah hutan), Apis florea, Apis cerana (lebah lokal) dan Apis mellifera (lebah Eropa) (Hadisoesilo 2001). Dari 34 Provinsi yang ada di Indonesia, hanya sebanyak 5 Provinsi yang dapat memproduksi madu yaitu Provinsi Nusa Tenggara Barat, Jawa Barat, Nusa Tenggara Timur, Sulawesi Tenggara dan Sumatera Barat (Badan Pusat Statistik 2012-2016). Kebutuhan akan madu di Indonesia untuk dikonsumsi secara langsung maupun digunakan sebagai bahan baku industri kosmetik/farmasi diperkirakan mencapai 10.000 - 15.000 ton/tahun (Bank Indonesia 2012). Tingginya permintaan akan madu yang tidak diimbangi oleh jumlah produksi madu nasional merupakan permasalahan yang penting. Sehingga peningkatan peningkatan jumlah produksi madu nasional perlu dilakukan untuk dapat memenuhi permintaan madu nasional maupun global (Sarah et al., 2019).

Peningkatan jumlah produksi madu nasional dengan cara pengembangan usaha budidaya lebah madu merupakan salah satu program yang dilakukan oleh KPHL Rinjani Barat di wilayah kerjanya. Selain untuk meningkatkan produksi, budidaya lebah madu juga dikatakan mampu untuk meningkatkan pendapatan masyarakat di sekitar kawasan hutan (El-Niweiri dan Moritz 2010; Gebremichael dan Gebremedhin 2014). Pengembangan usaha budidaya lebah madu di KPHL Rinjani Barat yang masih tergolong baru menyebabkan perlu dilakukannya penelitian untuk mencari informasi tentang kelayakan finansial usaha budidaya lebah madu dan penyusunan strategi pengembangan usaha budidaya lebah madu di KPHL Rinjani Barat. Serta menurut hasil penelitian yang dilakukan oleh Dewi, I.S (2018); Nugraha, A.A (2018) analisis kelayakan finansial suatu usaha memang penting untuk dilakukan guna pengembangan usaha yang masih baru.

\section{METODE}

\subsection{Lokasi Penelitian}

Penelitian ini dilakukan di Resort Malimbu, KPHL Rinjani Barat yang secara administratif terletak di dua Kabupaten yaitu Kabupaten Lombok Utara dan Kabupaten Lombok Barat, Provinsi Nusa Tenggara Barat. Penelitian ini dilakukan pada bulan April - Juni 2016.

Penelitian ini menggunakan metode pendekatan studi kasus dan menggunakan metode kuantitatif. Metode kuantitatif digunakan untuk mengetahui kelayakan usaha budidaya lebah madu Apis cerana di Resort Malimbu di KPHL Rinjani Barat, Provinsi NTB. Untuk pengambilan sampel KTH lebah madu dilakukan di wilayah Resort Malimbu. Pemilihan sampel lokasi penelitian ditentukan dengan cara purposive sampling dengan pertimbangan yaitu Resort Malimbu merupakan satu-satunya resort yang berada di dua Kabupaten berbeda dan KTH yang ada di Resort Malimbu memiliki jumlah stup/koloni terbanyak dibandingkan dengan KTH lebah madu lainnya di KPHL Rinjani Barat (KPHL Rinjani Barat, 2016), oleh karena itu Resort Malimbu dipilih dan dianggap mampu untuk mewakili KTH lebah madu yang ada di KPHL Rinjani Barat.

\subsection{Analisis Data}

\subsubsection{Analisis Biaya}

Analisis biaya dilakukan berdasarkan data biaya yang dikeluarkan oleh KTH madu untuk usaha budidaya lebah madu di kawasan Resort Malimbu. Analisis ini memberikan hasil berupa biaya per koloni untuk masing-masing komponen biaya. 


\subsubsection{Analisis Pendapatan}

Analisis pendapatan dilakukan berdasarkan taksiran pendapatan KTH madu di Resort Malimbu. Pendapatan ditaksir dari jumlah produksi madu dan harga penjualan madu di lokasi oleh KTH madu di Resort Malimbu. Analisis ini memberikan hasil produktivitas usaha budidaya lebah madu selama periode pengelolaan, yaitu 10 tahun yang digunakan berdasarkan umur ekonomis dari bangunan untuk stup lebah madu.

\subsubsection{Analisis Keuntungan}

Analisis ini bertujuan untuk melihat hasil budidaya lebah madu selama satu daur. Kelayakan usaha budidaya lebah madu di Resort Malimbu akan diolah menggunakan aliran kas tunai (cashflow). Data biaya dan manfaat yang telah diinput kedalam cashflow selanjutnya akan dianalisis menggunakan kriteria kelayakan usaha yaitu Break Even Point (BEP), Net Present Value (NPV), Benefit/Cost Ratio (B/C Ratio) Payback Period (PP) dan Internal Rate of Return (IRR). Periode usaha budidaya lebah madu berdasarkan umur ekonomis kandang lebah madu yaitu selama 10 tahun.

a. Break Even Point (BEP)

Break Even Point atau titik impas adalah keadaan dimana suatu usaha tidak mendapatkan laba dan juga tidak mengalami kerugian, artinya seluruh biaya yang dikeluarkan untuk kegiatan produksi dapat terbayarkan oleh hasil penjualan produk. Dalam suatu usaha terdapat dua jenis BEP yaitu BEP dalam satuan unit (Q) dan BEP dalam satuan rupiah (Rp). Perhitungan BEP menggunakan rumus sebagai berikut:

$$
B E P(Q)=\frac{F C}{P-V}
$$

Keterangan : $\mathrm{BEP}(\mathrm{Q})=$ Break even point dalam satuan unit

$\mathrm{FC} \quad=$ Biaya tetap

$\mathrm{P} \quad=$ Harga jual per unit

$\mathrm{V} \quad=$ Biaya variabel per unit

$$
B E P(R p)=\frac{F C}{1-\frac{V}{S}}
$$

Keterangan : $\mathrm{BEP}(\mathrm{Rp})=$ Break even point dalam satuan rupiah

$$
\begin{array}{ll}
\mathrm{FC} & =\text { Biaya tetap } \\
\mathrm{V} & =\text { Biaya variabel per unit } \\
\mathrm{S} & =\text { Volume penjualan }
\end{array}
$$

b. $\quad$ Net Present Value (NPV)

Net Present Value adalah selisih antara total manfaat present value dengan total biaya present value atau jumlah present value dari manfaat bersih tambahan selama umur bisnis. Nilai yang dihasilkan oleh perhitungan dalam satuan mata uang (Rupiah). Secara matematis dapat dirumuskan sebagai berikut:

$$
N P V=\sum_{t=0}^{n} \frac{B_{t}-C_{t}}{(1+i)^{t}}
$$

$$
\begin{aligned}
\text { Keterangan : } \mathrm{t} & =1,2, \ldots ., \mathrm{n} \\
\mathrm{n} & =\text { jumlah tahun } \\
\mathrm{i} & =\text { Tingkat bunga (diskonto) } \\
\mathrm{Bt} & =\text { Manfaat (benefit) yang diperoleh tiap tahun } \\
\mathrm{Ct} & =\text { Biaya (cost) yang dikeluarkan tiap tahun }
\end{aligned}
$$

Kerangka keputusan :

- NPV > 0 berarti secara finansial usaha layak untuk dilakukan karena manfaat yang diperoleh lebih besar dari biaya yang dikeluarkan.

- NPV < 0 berarti secara finansial usaha tidak layak untuk dilakukan karena manfaat yang diperoleh lebih kecil dari biaya yang dikeluarkan. 
c. Benefit/ Cost Ratio (B/C Ratio)

B/C Rasio adalah Nisbah manfaat terhadap biaya. Nilai mutlak B/C ratio akan berbeda tergantung pada tingkat bunga, semakin tinggi tingkat bunga semakin rendah $\mathrm{B} / \mathrm{C}$ ratio yang dihasilkan. Jika tingkat bunga yang dipilih cukup tinggi maka $\mathrm{B} / \mathrm{C}$ ratio akan kurang dari satu (Gitinger, 1986).

$$
B / C \text { ratio }=\frac{\sum_{t=1}^{t=n} \frac{B_{t}}{(1+i)^{t}}}{\sum_{t=1}^{t=n} \frac{C_{t}}{(1+i)^{t}}}
$$

$$
\begin{aligned}
\text { Keterangan }: \mathrm{t} & =1,2, \ldots ., \mathrm{n} \\
\mathrm{n} & =\text { jumlah tahun } \\
\mathrm{i} & =\text { Tingkat bunga (diskonto) } \\
\mathrm{Bt} & =\text { Manfaat }(\text { benefit) yang diperoleh tiap tahun } \\
\mathrm{Ct} & =\text { Biaya (cost) yang dikeluarkan tiap tahun }
\end{aligned}
$$

Kerangka keputusan :

- $\mathrm{B} / \mathrm{C}$ rasio > 1 maka usaha layak untuk dilakukan karena setiap pengeluaran akan menghasilkan penerimaan yang lebih besar.

- $\mathrm{B} / \mathrm{C}$ rasio < 1 maka usaha tidak layak untuk dilakukan karena setiap pengeluaran akan menghasilkan penerimaan yang lebih kecil.

d. Payback Period (PP)

Payback period atau tingkat pengembalian investasi merupakan salah satu metode penilaian kelayakan investasi yang telah lama digunakan. Payback period adalah jumlah tahun yang diperlukan untuk dapat mengembalikan investasi yang dikeluarkan dalam satu periode usaha (Dwiputra, G. A. 2017). Semakin cepat jangka waktu pengembalian investasi suatu usaha, maka semakin layak usaha tersebut untuk dilakukan.

$$
P P=\frac{I}{A_{b}}
$$

$$
\begin{aligned}
\text { Keterangan : I } & =\text { Investasi } \\
\mathrm{Ab} & =\text { jumlah tahun } \\
\mathrm{i} & =\text { Benefit yang diperoleh dalam satuan waktu }
\end{aligned}
$$

e. Internal Rate of Return (IRR)

IRR adalah nilai discount rate (i) yang membuat NPV dari suatu proyek sama dengan nol atau dapat membuat B/C sama dengan satu (Sartono, 2012). Secara matematis IRR dihitung menggunakan rumus:

$$
I R R=i_{1}+\frac{N P V 1}{N P V 1-N P V 2}\left(i_{2}-i_{1}\right)
$$

$$
\begin{array}{cl}
\text { Keterangan : } \mathrm{NPV}_{1} & =\mathrm{NPV} \text { yang bernilai positif } \\
\mathrm{NPV}_{2} & =\text { NPV yang bernilai negatif } \\
\mathrm{i}_{1} & =\text { Tingkat bunga yang menghasilkan NPV positif } \\
\mathrm{i}_{2} & =\text { Tingkat bunga yang menghasilkan NPV negatif }
\end{array}
$$

Kerangka keputusan :

- IRR > tingkat diskonto, maka usaha layak untuk dijalankan

- IRR < tingkat diskonto, maka usaha tidak layak untuk dijalankan

- $\mathrm{IRR}=$ tingkat diskonto, maka usaha tidak mendapatkan keuntungan maupun kerugian

\subsubsection{Asumsi Kelayakan Finansial}

Asumsi yang digunakan pada penelitian ini adalah :

1. Jumlah koloni diasumsikan tetap hingga akhir umur usaha.

2. Produktivitas koloni lebah madu tetap setiap tahunnya.

3. Pengeluaran untuk investasi dan harga faktor-faktor produksi didasarkan pada harga konstan

4. Harga jual dan faktor-faktor yang mempengaruhi dianggap tetap 
5. Ketersediaan sumber pakan tidak dipengaruhi oleh jumlah koloni yang dibudidayakan.

\section{HASIL DAN PEMBAHASAN}

\subsection{Karakteristik KTH Madu di Resort Malimbu KPHL Rinjani Barat}

Terdapat dua kelompok tani hutan (KTH) madu yang berada di Resort Malimbu, yaitu KTH Suka Maju II dan KTH Tegak Sari. Semua anggota KTH madu yang berada di Resort Malimbu merupakan laki-laki yang masih tergolong usia produktif (22-56 tahun). Dominasi laki-laki pada usaha budidaya lebah madu disebabkan oleh stup/kotak lebah yang berat serta seringnya pendakian untuk mendapatkan koloni atau memanen madu membutuhkan fisik yang kuat seperti yang umumnya dimiliki oleh laki-laki. Selain itu, perempuan juga jarang terlibat dalam budidaya lebah madu karena kegiatan pemanenan produk lebah madu memerlukan waktu yang relatif lama, sehingga secara tidak langsung akan menyita waktu perempuan untuk mengerjakan pekerjaan lainnya di rumah (Kleij dan Simukoko 2012).

Tani hutan merupakan pekerjaan utama yang dimiliki oleh responden yaitu sebanyak $86,67 \%$. Tani hutan yang dimaksud disini adalah masyarakat yang memiliki lahan di sekitar kawasan hutan, baik lahan pribadi maupun lahan negara yang diberikan kepada masyarakat dalam bentuk perjanjian Hutan Kemasyarakatan Sedangkan, untuk pekerjaan sampingan responden di Resort Malimbu adalah usaha budidaya lebah madu. Ini menunjukkan bahwa masyarakat sekitar hutan di Resort Malimbu sangat bergantung pada sumber daya hutan, dimana masyarakat sekitar hutan tidak akan bisa dipisahkan dengan sumber daya hutan atau memiliki keterkaitan yang erat (Cronkleton et al 2013). Mengingat bahwa kawasan hutan Resort Malimbu seluruhnya merupakan kawasan hutan lindung, akan lebih tepat jika adanya dukungan yang lebih untuk pengembangan pemanfaatan HHBK (Hasil Hutan Bukan Kayu) dan jasa lingkungan di kawasan tersebut kedepannya.

\subsection{Biaya Usaha Budidaya Lebah Madu}

Dalam penghitungan biaya usaha budidaya lebah madu, terdapat dua jenis biaya yang dikeluarkan yaitu biaya investasi dan biaya operasional. Modal yang digunakan untuk melakukan usaha budidaya lebah madu didapatkan dari dua sumber yaitu modal sendiri dan bantuan pemerintah. Anggota KTH lebah madu menggunakan modal sendiri untuk pengembangan usaha budidaya lebah madu jenis Apis cerana. Sedangkan pengembangan usaha budidaya lebah madu jenis Trigona sp mendapatkan bantuan modal usaha dari KPHL Rinjani Barat berupa koloni lebah dan stup lebah.

Biaya investasi yang dikeluarkan dalam usaha budidaya lebah madu terbagi menjadi major costs (biaya besar) dan minor costs (biaya kecil). Kebutuhan usaha budidaya lebah madu yang termasuk major costs adalah proses pembuatan stup lebah madu. Pembelian stup membutuhkan sebanyak $60 \%-$ $90 \%$ dari total biaya investasi yang dikeluarkan. Sehingga biaya yang dikeluarkan untuk pembuatan bangunan, pembelian koloni dan pembelian peralatan panen dapat dikategorikan sebebagai minor costs.

Biaya operasional dalam usaha budidaya lebah madu terdiri dari biaya kontrol lebah, biaya panen dan biaya pemerasan dan pengemasan. Anggota KTH lebah madu di Resort Malimbu melakukan usaha budidaya lebah madu secara swadaya, yang artinya seluruh kegiatan usaha dilakukan bersama-sama tanpa adanya upah. Namun semua kegiatan yang dilakukan untuk menjalankan usaha harus diperhitungkan secara nominal rupiah. Pendekatan yang digunakan yaitu dengan menggunakan jumlah upah harian untuk buruh bangunan di lokasi budidaya Resort Malimbu yaitu sebesar Rp. 10.000/jam.

\subsection{Pendapatan Budidaya Lebah Madu}

Pendapatan usaha budidaya lebah madu KTH di Resort Malimbu KPHL Rinjani Barat berasal dari penjualan madu. Produksi madu dari usaha budidaya lebah madu berbeda-beda untuk jenis Apis cerana dan Trigona sp. Berdasarkan pengalaman anggota $\mathrm{KTH}$, jenis Apis cerana mampu menghasilkan sebanyak $\pm 600 \mathrm{ml}$ madu/stup dengan masa tunggu panen selama 3 bulan dari pemindahan koloni ke stup baru. Sedangkan untuk jenis Trigona $s p$ mampu menghasilkan sebanyak $100-140 \mathrm{ml}$ madu/stup dengan masa tunggu panen selama 6 bulan dari pemindahan koloni ke stup baru. Kalender musim bunga dibuat untuk mengetahui ketersediaan pakan lebah madu di Resort Malimbu selama tiap bulan selama satu tahun. Ketersediaan sumber pakan sangat berpengaruh dengan jumlah madu yang dihasilkan. 
Sumber pakan untuk lebah madu di Resort Malimbu KPHL Rinjani Barat masih sangat berlimpah. Dari 21 jenis tanaman yang merupakan sumber pakan lebah madu, terdapat 5 jenis tanaman yang berbunga sepanjang tahun yaitu tanaman aren, kelapa, ketapang, lamtoro dan nangka. Sehingga lebah seharusnya dapat memproduksi madu sepanjang tahun. Produksi madu tertinggi dapat terjadi pada bulan Juni - Agustus, karena pada rentang bulan ini terdapat sebanyak 16 jenis tumbuhan yang berbunga. Sedangkan masa krisis pakan lebah berpotensi terjadi pada bulan September - Februari, karena pada rentang bulan ini sumber pakan yang tersedia lebih sedikit dibandingkan dengan bulan lainnya yaitu sebanyak 10 - 13 tumbuhan saja yang berbunga.

Madu yang diproduksi oleh KTH madu di Resort Malimbu KPHL Rinjani Barat dikemas dan dijual dalam bentuk botol berukuran $600 \mathrm{ml}$ untuk kedua jenis lebah madu. Harga jual madu dengan ukuran botol 600 ml yaitu sebesar Rp. 150.000 untuk jenis Apis cerana dan Rp. 200.000 untuk jenis Trigona sp. Jumlah pendapatan yang diperoleh sangat berkaitan dengan jumlah pemanenan yang dilakukan per tahunnya. Karena terdapat masa tunggu panen selama 3 bulan untuk jenis Apis cerana dan 6 bulan untuk jenis Trigona sp, maka pendapatan yang diperoleh tiap tahunnya selama 10 tahun berbeda-beda.

\subsection{Keuntungan Usaha Budidaya Lebah Madu}

Keuntungan usaha budidaya lebah madu di Resort Malimbu KPHL Rinjani Barat merupakan selisih antara harga jual dengan harga pokok produk madu dalam satu periode usaha (10 tahun). Keuntungan yang diperoleh berbeda antara KTH Suka Maju II dengan KTH Tegak Sari. KTH Suka Maju II mendapatkan keuntungan yang lebih besar dari hasil usaha budidaya lebah madu jenis Trigona $s p$ dibandingkan dengan hasil usaha budidaya lebah madu jenis Apis cerana. Hal ini dikarenakan jumlah koloni/stup yang dimiliki oleh KTH Suka Maju II lebih banyak untuk jenis Trigona $s p$ yaitu sebanyak 150 stup daripada jenis Apis cerana yaitu hanya sebanyak 17 stup saja.

Sedangkan untuk KTH Tegak Sari, keuntungan paling banyak diperoleh dari usaha budidaya lebah madu jenis Apis cerana. Hal ini dipengaruhi oleh kuantitas produksi madu yang dihasilkan oleh lebah madu jenis Apis cerana lebih banyak yaitu sebanyak $600 \mathrm{ml} /$ stup dibandingkan dengan lebah madu jenis Trigona $s p$ yang hanya menghasilkan $120 \mathrm{ml} / \mathrm{stup}$. Dari analisis keuntungan yang dihitung dapat dikatakan bahwa semakin banyak jumlah koloni/stup yang dimiliki maka akan semakin banyak juga keuntungan yang diperoleh, atau jumlah koloni/stup memiliki pengaruh yang linier terhadap keuntungan. Namun hubungan linier antara jumlah koloni/ stup dengan keuntungan ini dapat terjadi dengan asumsi bahwa sumber pakan lebah pada lokasi budidaya tercukupi untuk semua koloni lebah madu yang dibudidayakan.

\subsection{Keuntungan Usaha Budidaya Lebah Madu}

Hasil perhitungan kelayakan finansial usaha budidaya lebah madu Apis cerana dan Trigona $s p$ di KTH Suka Maju II dan KTH Tegak Sari dapa dilihat pada Tabel 1 dan Tabel 2.

Tabel 1. Kelayakan finansial usaha budidaya lebah madu KTH Suka Maju II

\begin{tabular}{ccc}
\hline \multirow{2}{*}{ Kriteria kelayakan } & \multicolumn{2}{c}{ KTH Suka Maju II } \\
\cline { 2 - 3 } & Apis cerana & Trigona sp \\
\hline BEP & $2.704 \mathrm{ml}$ atau Rp. 676.080 & $7.327 \mathrm{ml}$ atau Rp. 2.442 .193 \\
NPV & Rp. 104.229.381,28 /10 thn & Rp. 45.491.153,36/10 thn \\
B/C R & 2,85 & 1,21 \\
PP & 2,52 thn & 4,36 thn \\
IRR & $40,92 \%$ & $23,52 \%$ \\
\hline
\end{tabular}

Tabel 2. Kelayakan finansial usaha budidaya lebah madu KTH Tegak Sari

\begin{tabular}{ccc}
\hline \multirow{2}{*}{ Kriteria kelayakan } & \multicolumn{2}{c}{ KTH Tegak Sari } \\
\cline { 2 - 3 } & Apis cerana & Trigona sp \\
BEP & 10.749 ml atau Rp. 2.687.204 & 9.222 ml atau Rp. 3.073.948 \\
NPV & Rp. 1.036.687.824,32/10 thn & Rp. 92.973.767,05/10 thn \\
B/C R & 5,79 & 1,34 \\
PP & 1,39 thn & 4,12 thn \\
IRR & $42,34 \%$ & $27,91 \%$ \\
\hline
\end{tabular}

Nilai BEP terendah terdapat pada KTH Suka Maju II dengan jenis lebah Apis cerana. Keadaan dimana KTH tidak mendapatkan keuntungan dan tidak mengalami kerugian atau impas akan terjadi 
jika KTH Suka Maju II dapat menghasilkan unit madu sebanyak $2.704 \mathrm{ml}( \pm 5$ botol $600 \mathrm{ml})$ atau memperoleh pendapatan penjualan madu sebesar Rp. 676.080 dalam satu kali produksi atau panen madu. Sedangkan nilai BEP tertinggi terdapat pada KTH Tegak Sari dengan jenis Apis cerana. Keadaan impas akan terjadi jika KTH tegak sari dapat menghasilkan unit madu sebanyak $10.749 \mathrm{ml}( \pm$ 18 botol $600 \mathrm{ml}$ ) atau memperoleh pendapatan penjualan madu sebesar Rp. 2.687.204 dalam satu kali produksi atau panen madu. Perbedaan nilai BEP dalam perhitungan dipengaruhi oleh jumlah koloni/stup yang dimiliki oleh tiap KTH.

Kriteria kelayakan usaha NPV (Net Present Value) pada usaha budidaya lebah madu jenis Apis cerana dan Trigona $s p$ memiliki nilai > 0 pada kedua kelompok. Hal ini berarti bahwa selama 10 tahun investasi, usaha budidaya lebah madu di Resort Malimbu akan menghasilkan keuntungan untuk KTH Suka Maju II dan KTH Tegak Sari secara berurutan sebesar Rp. 104.229.381,28 /10 tahun dan Rp. 1.036.687.824,32 /10 tahun untuk budidaya lebah jenis Apis cerana dan Rp. 45.491.153,36 /10 tahun dan Rp. 92.973.767,05 /10 tahun untuk budidaya lebah jenis Trigona sp. Didapatkannya hasil perhitungan dengan nilai NPV yang positif atau NPV > 0 menandakan bahwa usaha budidaya lebah madu yang dilakukan oleh KTH di Resort Malimbu KPHL Rinjani Barat layak untuk dilakukan.

Kriteria kelayakan usaha B/C R (Benefit/ Cost Ratio) merupakan kriteria yang bertujuan untuk mengukur besar manfaat yang akan didapatkan dari biaya yang dikeluarkan untuk menjalankan suatu usaha. Nilai B/C R dari kedua jenis lebah madu Apis cerana dan Trigona sp, secara berurutan yaitu 2,85 dan 1,21 untuk KTH Suka Maju II dan 5,79 dan 1,34 untuk KTH Tegak Sari. Usaha dikatakan layak untuk dilakukan jika memiliki nilai B/C R $>1$. Sebagai contoh yaitu nilai B/C R dari KTH Tegak Sari sebesar 5,79 yang artinya bahwa setiap Rp.1 biaya yang dikeluarkan akan menghasilkan manfaat sebanyak Rp. 5,79. Hasil perhitungan menunjukkan nilai B/C R dari usaha budidaya lebah madu lebih dari satu, sehingga usaha budidaya lebah madu yang dilakukan oleh KTH di Resort Malimbu KPHL Rinjani Barat layak untuk dilakukan.

Kriteria kelayakan usaha Payback Period digunakan untuk mengetahui jangka waktu yang diperlukan untuk mengembalika investasi usaha. Semakin kecil nilai payback period yang didapat menunjukkan bahwa semakin cepat waktu yang diperlukan untuk dapat mengembalikan investasi yang telah dikeluarkan. Pada KTH Suka Maju II payback period dari usaha budidaya lebah madu jenis Apis cerana memiliki nilai yang lebih kecil yaitu 2,52 tahun atau 30 bulan dibandingkan dengan usaha budidaya lebah madu jenis Trigona sp yaitu 4,36 tahun atau 52 bulan. Sedangkan nilai payback period dari KTH Tegak Sari yaitu 1,39 tahun atau 17 bulan untuk Apis cerana dan 4,12 tahun atau 49 bulan untuk Trigona sp. Hal ini menjelaskan bahwa untuk usaha budidaya lebah madu jenis Apis cerana diperlukan waktu sebanyak 1,39-2,52 tahun untuk dapat mengembalikan investasi yang dikeluarkan, sedangkan untuk usaha budidaya lebah madu jenis Trigona sp diperlukan waktu sebanyak 4,12 - 4,36 tahun untuk mengembalikan investasi yang dikeluarkan. Usaha dikatakan layak jika masa pengembalian investasi /payback period lebih kecil atau lebih cepat daripada daur/ periode usaha. Dari hasil perhitungan payback period yang memiliki nilai lebih kecil dari pada periode usaha yaitu 10 tahun maka dapat dikatakan usaha budidaya lebah madu di Resort Malimbu KPHL Rinjani Barat layak untuk dilakukan.

Internal Rate of Return atau IRR merupakan kriteria kelayakan usaha yang bertujuan memberikan gambaran besarnya nilai pengembalian modal yang dikeluarkan. Dalam perhitungannya, usaha dikatakan layak jika nilai IRR > suku bunga yang digunakan saat ini. Dapat dilihat bahwa nilai IRR dari usaha budidaya lebah madu jenis Apis cerana dan Trigona sp yaitu sebesar 40,92\% dan 22,52 \% untuk KTH Suka Maju II dan 42,34\% dan 27,91\% untuk KTH Tegak Sari. Kedua KTH yang membudidayakan dua jenis lebah madu memiliki IRR > $20 \%$. Usaha budidaya lebah madu KTH di Resort malimbu layak untuk dilakukan karena memiliki nilai IRR yang lebih besar daripada nilai suku bunga riil yaitu sebesar $6,96 \%$.

\section{KESIMPULAN DAN SARAN}

\subsection{Kesimpulan}

Usaha budidaya lebah madu yang dilakukan oleh KTH lebah madu di Resort Malimbu layak secara finansial, dengan nilai kriteria kelayakan investasi sebagai berikut. Usaha budidaya lebah madu yang dilakukan KTH Suka Maju II layak secara finansial, dengan nilai NPV = Rp. 26.252.469,18, B/C R = 1,27 dan IRR $=31,91 \%$ untuk lebah madu jenis Apis cerana. Sedangkan nilai kriteria kelayakan investasi untuk lebah madu jenis Trigona sp yaitu NPV $=$ Rp. 96.764.781,19, B/C R $=1,50$ dan IRR $=31,82 \%$. Usaha budidaya lebah madu yang dilakukan KTH Tegak Sari layak secara finansial, dengan nilai NPV = Rp. 974.423.078,17, B/C R = 
4,94 dan IRR $=42,16 \%$ untuk lebah madu jenis Apis cerana. Sedangkan nilai kriteria kelayakan investasi untuk lebah madu jenis Trigona sp yaitu NPV $=$ Rp. 253.485.374,74, B/C R = 2,31 dan IRR = 36,63\%.

\subsection{Saran}

Perlu dilakukan penelitian lanjutan terkait dengan kajian kelayakan usaha budidaya lebah madu dengan pengelolaan yang lebih intensif, baik dari jumlah koloni yang lebih banyak, teknik pembudidayaan yang lebih baik maupun teknik pemanenan madu yang lebih efektif. Hal ini berguna sebagai pembanding kajian usaha budidaya lebah madu tradisional/swadaya yang telah diteliti.

\section{UCAPAN TERIMA KASIH}

Penelitian ini dibiayai oleh Program In Search of Balance Batch 3 atas kerja sama Universitas Gadjah Mada dan Universitas Agder Norwegia.

\section{DAFTAR PUSTAKA}

Bertrand, O. (1994). Education and Work. Pages: 5-8. Paris, UNESCO.

Badan Pusat Statistik. (2016). Nusa Tenggara Barat dalam angka. Pages: 235. Badan Pusat Statistik Provinsi Nusa Tenggara Barat.

Badan Pusat Statistik. 2012-2016. Jawa Barat dalam angka. Pages: 261-374. Badan Pusat Statistik Provinsi Jawa Barat.

Badan Pusat Statistik. (2016). Nusa Tenggara Timur dalam angka. Pages: 240-320. Badan Pusat Statistik Provinsi Nusa Tenggara Timur.

Badan Pusat Statistik. (2016). Sulawesi Tenggara dalam angka. Pages: 291-338. Badan Pusat Statistik Provinsi Sulawesi Tenggara.

Badan Pusat Statistik. (2016). Sumatera Barat dalam angka. Pages: 354-468. Badan Pusat Statistik Provinsi Sumatera Barat.

Bank Indonesia. 2012. Pola pembiayaan usaha kecil (PPUK): Budidaya lebah madu. Pages: 11. Tersedia pada http://www.bi.go.id/id/umkm/kelayakan/pola-pembiayaan/ peternakan/documents/ 4f32c79c16a64d9aad5cec0e4b712 ba6budidayalebahmadu1.pdf (diakses januari 2016).

Bishop, J.T. (1999). Valuing Forests: A Review of Methods and Applications in Developing Countries. Pages 38-45. International Institute for Environment and Development. London.

Chen, W., Xu, D., \& Liu, J. (2015). The forest resourcers unput-uotput model: An application in China. Ecological Indicators 51: 87-97.

Cronkleton, P., Larson, A. M., Feintrenie, L., Garcia, C., \& Levang, P. 2013. Reframing Commuity Forestry to Manage The Forest-Farm Interface. Small-scale Forestry 12: 5 - 13.

Damette, O., \& Dalcote, P. (2011). Unsustainable timber harvesting, deforestation and the role of certification. Ecological Economics 70: 1211-1219.

Dewi, I. S. (2018). Analisis Kelayakan Finansial Budidaya Lebah Madu di Desa Kuapan Kecamatan Tambang Kabupaten Kampar (Kasus Usaha Madu "Mekar Sari”). Jurnal Agribisnis, 20 (1), 35-51.

Dupas, P., Green, S., Keats, A., \& Robinson, J. (2012). Challenges in banking the rural poor : Evidence from Kenya's western province. National Bureau Of Economic Research : 1-19.

Dwiputra, G. A. (2017). Analisis Kelayakan Pengembangan Usaha Rumah Makan Krebo Jantan. Jurnal Sistem Dan Manajemen Industri, 1(2), 85-90.

El-Niweiri, M. A. A., \& Moritz, R. F. A. (2009). The impact of apiculture on the genetic structure of wild honeybee populations (Apis mellifera) in Sudan. Jourrnal of Insect Conservation 14: 115-124.

Gebremichael, B., \& Gebremedhin, B. (2014). Adoption of improved box hive technology: Analysis of smallholder farmers in Northern Ethiopia. Journal of Agriculturan Economics 2: 77-82.

Hadisoesilo, S. (2001). Keanekaragaman spesies lebah madu asli Indonesia. Biodiversitas 2: 123-128.

Hilmi, M., Nicola, B., \& Danilo, M. (2011). Beekeeping and Sustainable Livelihoods. Pages: 2-22. Food and Agriculture Organization of the United Nations. Rome.

Kleij, C. V. D., \& Simukoko, M. (2012). Women Participation In Beekeeping In Zambia Through The Use Of Technological Innovation. SNV Netherlands Development Organisation 1-4. 
Nugraha, A. A. (2018). Analisis Kelayakan Finansial Produk Madudi Cv. Kembang Joyo Kecamatan Karang Ploso Kabupaten Malang (Doctoral Dissertation, University Of Muhammadiyah Malang).

Rangkuti, F. (2009). Strategi Promosi Yang Kreatif dan Analisis Kasus Integrated Marketing Communication. Pages: 241-244. Jakarta, PT. Gramedia Pustaka Utama.

Sarah, D., Suryana, R. N., \& Kirbrandoko, K. (2019). Strategi Bersaing Industri Madu (Studi Kasus: CV Madu Apiari Mutiara). Jurnal Aplikasi Bisnis dan Manajemen (JABM), 5(1), 71-71

Sartono, A.(2012). Manajemen keuangan: Teori dan aplikasi. Ed keempat. Yogyakarta: BPFE Yogyakarta

Sisak, L., Riedl, M., \& Dudik, R. (2016). Non-market non-timber forest products in the Czech Republic their socio-economic effects and trends in forest land use. Land Use Policy 50: 390-398.

Sumargo, W., Nanggara, S. G., Nainggolan, F. A., \& Apriani, I. (2011). Potret Keadaan Hutan Indonesia : Periode Tahun 2000-2009. Pages: 15-29. Forest Watch Indonesia. Indonesia.

UNESCO. (2012). Education and Skills for Inclusive and Sustainable Development Beyond 2015. Tersedia pada http://www.un.org/millenniumgoals/pdf/Think \%20Pieces/4education.pdf (diakses oktober 2016).

Sartono, A.(2012). Manajemen keuangan: Teori dan aplikasi. Ed keempat. Yogyakarta: BPFE Yogyakarta. 
[Halaman ini sengaja dikosongkan] 